\title{
PLACE AND ROLE OF FOOD INDUSTRY IN MODERN ECONOMIES
}

\author{
Z. LAKNER*a and J. POPP ${ }^{\mathrm{b}}$ \\ ${ }^{a}$ Department of Food Economics, Faculty of Food Science, Corvinus University, \\ H-1118 Budapest, Villányi út 35. Hungary \\ ${ }^{\mathrm{b}}$ Institute of Sectoral Economics and Methodology, Department of Agricultural Economics, Faculty of Economics \\ and Business, Debrecen University, 4032 Debrecen, Böszörményi út 138. Hungary
}

(Received: 9 April 2014; accepted: 5 August 2014)

\begin{abstract}
In a period of economic crisis, there is a constantly increasing need to have a general picture on the place and role of different branches in fabrics of modern, open national economies. Based on Leontief's input-output model, using the unified, structural database of OECD, the article analyses the economic role of the food industry in national economies of OECD member states as well as in economic structure of some important emerging markets by approach of network analysis. Applying this unique combination of a comprehensive database and network analysis methods, it is proven that the centrality of the food industry, determined on the basis of these indicators, is much higher than the average of other sectors of the national economies. This fact can be explained by the specific "bridge" role of the food industry between the different sectors of national economy. Results have proven the importance of the food industry and highlight the necessity of revision of governmental resource-allocation principles for $\mathrm{R}+\mathrm{D}$ and industrial policy in member-states of the European Union.
\end{abstract}

Keywords: centrality measures, Leontief model, network analysis, structural modelling

Food industry is generally considered as a low-tech (Tunzelmann \& Acha, 2005), rather traditional sector of the national economies (Food-MAC, 2012). According to a recent study of the University of Cambridge: "The common perception of the food and drink industry is one which involves low value companies with production process that date back to the dark ages" (IFM, 2010). It is well-documented, that the economic weight of its original, traditionally most important partner, agriculture, in the long-run has been constantly decreasing (KuZNETS, 1971). At the same time, we do not have reliable, well-founded study on the place and role of the food industry in modern economies, however, this should be important for the determination of the key drivers of economic development (RAPETTI, 2013). In case of crisis-stricken economies, governments try to boost the economic development by centralised economic development funds (VIS et al., 2011). It seems to be essential to know the potential driving forces of economic development in case of re-allocation of governmental resources. The aim of the current article is to analyse two hypotheses:

$\mathrm{H}_{1}$ : food industry plays a central role in most of the national economies, because its input-structure joins mainly to agriculture as well as to some part of industry, and (at the same time) it is an important partner of trade;

$\mathrm{H}_{2}$ : supposed central role of the food industry is decreasing as the economy develops: in case of lower developed national economies this role of food industry is much more expressed than in case of developed economies.

\footnotetext{
* To whom correspondence should be addressed.

Phone/fax: +36-1-209-0961; e-mail: zoltan.lakner@uni-corvinus.hu
} 
Based on the analysis of these two hypotheses, we will be able to get a realistic picture on the current place and role of food industry in national economies in the post-industrial age.

\section{Methods}

\subsection{Application of network analysis to input-output models}

Different sectors in the production structure of a national economy can be distinguished, because they offer specific goods and services, by processing technologies, and logistical structure, which is characteristic to the given sector (Stockman, 1988). The historical breakthrough in analysis has been brought by comprehensive work of LEONTIEF (1941). According to the Leontief model an economy has $n$ sectors. Each sector produces $x_{\mathrm{i}}$ units of a simple and homogenous good. It is assumed that the $i_{\text {th }}$ sector, with purpose of production one unit, must use $a_{\mathrm{ij}}$ units from sector $j$. Furthermore, it is assumed that each sector sells some of its output to other sectors (intermediate output) and some of its output to consumers (final output). The final output of the $i_{\text {th }}$ sector is $d_{i}$.

The production of $x i$ sector can be expressed as:

$$
x_{\mathrm{i}}=a_{1 \mathrm{i}} x_{1}+a_{2 \mathrm{i}} x_{2}+\ldots+a_{\mathrm{ni}} x_{\mathrm{n}}+d_{\mathrm{i}}
$$

Equation 1 expresses that the total output equals intermediate output plus final output. Let $\mathrm{A}$ be the matrix of $a_{\mathrm{ij}}$ coefficients. If we denote the total output of the system by vector $\mathrm{x}$ and $d$ is the vector of final demand, then the economy can be described as:

$$
x=\mathrm{A} x+d
$$

which after re-writing becomes $\quad(\mathrm{I}-\mathrm{A}) x=d$

The input-output table can be interpreted as a network, and to its investigation the network-analysis, this new interdisciplinary approach (ALBERT \& BARABÁsI, 2002), can be applied (BorgatTi \& Li, 2009). The network analysis considers the relationships between entities as a graph. This is another approach of the traditional input-output analysis methodology. This graph $\mathrm{A}=(\mathrm{V}, \mathrm{E})$ consists of a set of vertices/nodes $(\mathrm{V})$ and a set of edges (E). In our case the vertices are the sectors, and the edges are the value-flows between them. In our analysis each edge $(i, j)$ is directed and has a non-negative weight, $a_{\mathrm{ij}}$. By definition the graph may contain self-loops because a given industry can be a consumer of its own products. The number of vertices is $n$. Put in another way, the graph can be represented as an $n \times n$ adjacency matrix, elements of which represents the usage of output of $a_{\mathrm{i}}$ sector to $a_{\mathrm{j}}$ sector (LAVE, 1995).

To understand the relative importance of different sectors in value flow, we have to apply the centrality concepts of network analysis. However, considerable research efforts have been invested on the study of centrality concept in network science, centrality is still an elusive concept that may be approximated from different perspectives, where different centrality measures are available (ABBAsi et al., 2012). 
The betweenness centrality $(v)$ of a node $v$ is given by expression:

$$
g(v)=\sum_{s \neq v \neq t} \sigma_{s t}(v)^{/} \sigma_{s t}
$$

where $\sigma_{\text {st }}$ is the total number of shortest paths form node $s$ to node (sector) and $\sigma_{\text {st }}(v)$ is the number of those paths (monetary flow) that pass through $v$. In a weighted network, the links connecting the nodes are no longer treated as binary interactions, but are weighted in proportion to the intensity of flows between them, e.g. the $a_{\mathrm{ij}}$ values (KIM et al., 2012).

We have determined different metrics of centrality. The centrality-measures applied by us were as follows:

- Eigenvector centrality (FrEEMAN, 1979).

- Bonacich's centrality (BONACICH, 1987).

- Total degree centrality is a combination of in-degrees (links inwards from other vertices) and out-degree (links towards other vertices) (OpSAHL et al., 2010).

- Prestige-measures (FAust \& WASSERMAn, 1992), hub-centrality (CoHEN et al., 1969; Kleinberg, 1999) and authority centrality (KLeInBerG, 2000).

\subsection{Data sources}

We have used the database of the Organisation for Economic Co-operation and Development (OECD, 2014). The electronic database of OECD comprises input-output tables for 34 developed countries. Additionally, the statistical database of OEDC contains data from new, important emerging markets, offering a standard cross-country comparison of input-output matrices for a wide array of mostly advanced industrial countries. The database contains data on 37 sectors of the national economies. In case of most of the countries, sector "Private households with employed persons" does not contain data, that is why we have omitted this part of the table. In this way we have used a $36 \times 36$ square matrix. The OECD database is constructed on the base of data supply of national official statistical organisations, based on a common theoretical and methodological platform, using a unified sartorial classification system. The international comparison of different input-output matrices has some error-term, as a consequence of (1) different confidentiality restrictions; (2) lack of detailed data; (3) differences in size and distribution of the black (illegal) and gray (semi-legal) enterprises, but, taking all factors into consideration, it permits a "fairly accurate cross country comparison" (FISHER \& VEGA-REDONDO, 2006).

\section{Results and discussion}

The betweenness centrality of the food industry has been relatively high in the case of most of the states. The highest betweenness values have characterised the Turkish $(0.125)$, the Indian (0.110), and the Argentinean (0.104) food sectors.

Bonacich power centrality has shown relatively large differences for individual branches in case of different countries. This is a consequence of the algorithm, applied for the calculation of this indicator. That is why, as a consequence of high magnitude of standard deviation, this centrality indicator does not lend itself for the international comparison.

Authority-, hub-, eigenvalue-, and total-degree centralities of the food industry in numerous cases have been significantly higher than the corresponding indicators for the average of national economies (Table 1). We have separately compared the different 
characteristic centrality indicators of some branches of national economies investigated with that of the food industry. Our results have proven that centrality indicators of the food industry, even in most developed industrial countries, have been significantly higher than the centrality indicators of "high tech" branches, e.g. machinery industry, motor vehicle production, or computer technology. (Due to limited space, these values will not be presented in tables, but they are obtainable, upon request, from the authors.)

Table 1. Authority centrality, Hub centrality, In- and total-degree centrality of food industry

\begin{tabular}{|c|c|c|c|c|c|c|c|c|}
\hline \multirow[t]{2}{*}{ Country } & \multicolumn{2}{|c|}{ Authority centrality } & \multicolumn{2}{|c|}{ Hub centrality } & \multicolumn{2}{|c|}{ Eigenvalue centrality } & \multicolumn{2}{|c|}{ Total-degree centrality } \\
\hline & $\begin{array}{l}\text { Food } \\
\text { industry }\end{array}$ & $\begin{array}{l}\text { Nat. econ. } \\
\text { average }\end{array}$ & $\begin{array}{c}\text { Food } \\
\text { industry }\end{array}$ & $\begin{array}{l}\text { Nat. econ. } \\
\text { average }\end{array}$ & $\begin{array}{l}\text { Food } \\
\text { industry }\end{array}$ & $\begin{array}{l}\text { Nat. econ. } \\
\text { average }\end{array}$ & $\begin{array}{c}\text { Food } \\
\text { industry }\end{array}$ & $\begin{array}{c}\text { Nat. econ. } \\
\text { average }\end{array}$ \\
\hline Argentine & $0.898 *$ & 0.138 & $0.914^{*}$ & 0.128 & $0.679 *$ & 0.138 & $0.036^{*}$ & 0.01 \\
\hline Austria & 0.241 & 0.180 & 0.084 & 0.175 & 0.116 & 0.178 & 0.017 & 0.019 \\
\hline Australia & $0.225^{*}$ & 0.123 & 0.169 & 0.144 & 0.091 & 0.136 & $0.033^{*}$ & 0.018 \\
\hline Belgium & $0.252 *$ & 0.150 & 0.143 & 0.160 & 0.183 & 0.164 & 0.017 & 0.013 \\
\hline Bulgaria & $0.499 *$ & 0.161 & 0.075 & 0.142 & 0.015 & 0.015 & 0.015 & 0.015 \\
\hline Brazil & $0.651^{*}$ & 0.149 & $1.000^{*}$ & 0.147 & $0.573^{*}$ & 0.184 & $0.059^{*}$ & 0.015 \\
\hline Canada & 0.228 & 0.193 & 0.101 & 0.181 & 0.154 & 0.199 & 0.023 & 0.021 \\
\hline $\begin{array}{l}\text { Switzer- } \\
\text { land }\end{array}$ & 0.239 & 0.168 & 0.140 & 0.161 & 0.169 & 0.156 & 0.015 & 0.013 \\
\hline Cyprus & $0.504^{*}$ & 0.170 & $0.353^{*}$ & 0.182 & $0.296^{*}$ & 0.169 & $0.028 *$ & 0.016 \\
\hline Chile & $0.444 *$ & 0.194 & 0.101 & 0.184 & $0.336^{*}$ & 0.192 & $0.042 *$ & 0.028 \\
\hline Czech & 0.227 & 0.178 & 0.086 & 0.172 & 0.143 & 0.173 & 0.025 & 0.022 \\
\hline Germany & $0.269^{*}$ & 0.179 & 0.033 & 0.153 & 0.107 & 0.172 & 0.015 & 0.018 \\
\hline Denmark & $0.257^{*}$ & 0.135 & 0.090 & 0.169 & 0.161 & 0.157 & $0.014 *$ & 0.009 \\
\hline Estonia & $0.325^{*}$ & 0.153 & 0.090 & 0.178 & 0.122 & 0.163 & 0.009 & 0.012 \\
\hline Finland & 0.260 & 0.180 & 0.183 & 0.188 & 0.155 & 0.186 & 0.028 & 0.022 \\
\hline France & 0.272 & 0.169 & 0.085 & 0.155 & 0.148 & 0.166 & 0.022 & 0.021 \\
\hline Greece & $0.534 *$ & 0.159 & $0.517^{*}$ & 0.171 & 0.291 & 0.167 & 0.036 & 0.016 \\
\hline Hungary & $0.391 *$ & 0.190 & 0.123 & 0.177 & 0.198 & 0.186 & 0.016 & 0.014 \\
\hline Indonesia & $0.855^{*}$ & 0.138 & $0.839^{*}$ & 0.140 & $0.809^{*}$ & 0.128 & $0.037 *$ & 0.013 \\
\hline Ireland & $0.468^{*}$ & 0.190 & 0.182 & 0.123 & 0.177 & 0.156 & 0.014 & 0.012 \\
\hline Israel & 0.175 & 0.172 & 0.177 & 0.186 & 0.075 & 0.175 & 0.017 & 0.014 \\
\hline India & $0.546^{*}$ & 0.161 & 0.249 & 0.161 & 0.159 & 0.161 & $0.025^{*}$ & 0.016 \\
\hline Italy & $0.323 *$ & 0.176 & $0.294 *$ & 0.181 & 0.228 & 0.17 & $0.047^{*}$ & 0.028 \\
\hline Japan & 0.296 & 0.194 & 0.285 & 0.211 & 0.185 & 0.185 & 0.020 & 0.014 \\
\hline Korea & 0.082 & 0.155 & 0.132 & 0.164 & 0.078 & 0.177 & 0.015 & 0.011 \\
\hline Malta & $0.317^{*}$ & 0.170 & $0.453^{*}$ & 0.179 & 0.174 & 0.168 & 0.005 & 0.003 \\
\hline Mexico & $0.520^{*}$ & 0.180 & $0.529^{*}$ & 0.176 & $0.383^{*}$ & 0.171 & $0.043 *$ & 0.018 \\
\hline Netherland & $0.281^{*}$ & 0.169 & $0.316^{*}$ & 0.182 & 0.234 & 0.172 & $0.036^{*}$ & 0.019 \\
\hline
\end{tabular}


Table 1. cont

\begin{tabular}{lcccccccc}
\hline Country & \multicolumn{2}{c}{$\begin{array}{c}\text { Authority centrality } \\
\text { Food }\end{array}$} & \multicolumn{2}{c}{ Hub centrality } & \multicolumn{2}{c}{ Eigenvalue centrality } & \multicolumn{2}{c}{ Total-degree centrality } \\
industry & average & $\begin{array}{c}\text { Food } \\
\text { industry }\end{array}$ & $\begin{array}{c}\text { Nat. econ. } \\
\text { average }\end{array}$ & $\begin{array}{c}\text { Food } \\
\text { industry }\end{array}$ & $\begin{array}{c}\text { Nat. econ. } \\
\text { average }\end{array}$ & $\begin{array}{c}\text { Food } \\
\text { industry }\end{array}$ & $\begin{array}{c}\text { Nat. econ. } \\
\text { average }\end{array}$ \\
\hline New & $0.750^{*}$ & 0.151 & 0.189 & 0.168 & $0.635^{*}$ & 0.154 & $0.039^{*}$ & 0.017 \\
Zealand & & & & & & & & \\
Poland & $0.596^{*}$ & 0.175 & 0.215 & 0.177 & $0.494^{*}$ & 0.169 & $0.044^{*}$ & 0.026 \\
Portugal & $0.383^{*}$ & 0.177 & 0.176 & 0.171 & 0.213 & 0.169 & 0.020 & 0.013 \\
Romania & $0.766^{*}$ & 0.155 & $0.282^{*}$ & 0.146 & $0.545^{*}$ & 0.153 & $0.035^{*}$ & 0.013 \\
Russia & $0.338^{*}$ & 0.143 & 0.134 & 0.125 & $0.299^{*}$ & 0.136 & $0.029^{*}$ & 0.013 \\
Sweden & 0.205 & 0.179 & 0.069 & 0.178 & 0.125 & 0.176 & 0.012 & 0.015 \\
Slovakia & 0.247 & 0.178 & 0.083 & 0.168 & 0.113 & 0.176 & 0.009 & 0.012 \\
Slovenia & 0.204 & 0.176 & 0.117 & 0.174 & 0.120 & 0.174 & 0.022 & 0.018 \\
Turkey & 0.007 & 0.790 & 0.051 & 0.776 & 0.120 & 0.642 & 0.007 & 0.031 \\
Taiwan & 0.068 & 0.162 & 0.051 & 0.143 & 0.014 & 0.142 & 0.005 & 0.006 \\
United & 0.163 & 0.158 & 0.148 & 0.162 & 0.206 & 0.167 & 0.024 & 0.016 \\
Kingdom & & & & & & & & \\
United & 0.201 & 0.174 & 0.068 & 0.171 & 0.129 & 0.175 & 0.015 & 0.018 \\
States & & & & & & & & \\
Vietnam & $0.944^{*}$ & 0.092 & 0.606 & 0.154 & 0.420 & 0.128 & 0.015 & 0.005 \\
South- & $0.331^{*}$ & 0.165 & 0.275 & 0.162 & 0.150 & 0.151 & $0.033^{*}$ & 0.018 \\
Africa & & & & & & & & \\
\hline
\end{tabular}

* indicates the significant differences at $\mathrm{P}=95 \%$ level between centrality indicators of food (own calculations)

An explanation of this fact is the specific input and output structure of the food industry: cluster analysis of input-output structure of EU (27) economies proves, that the inputstructure of the food industry can be characterised as similar to agriculture (Fig. 1). Based on their input-structure, agriculture and food industry are characteristically different from other sectors of the national economies. Analysing the figure it is obvious that based on their inputstructure there is a relatively high level of similarity between the industrial sectors, but the food industry characteristically differs from other industrial branches. This can be explained by high level of utilisation of industrial as well as agricultural inputs. Analysing the output structure of different branches in the economies it is obvious that a considerable part of branches have some similarity (they form a part of larger clusters). In case of food industry, the difference is obvious: compared with some other sectors (e.g. transport, construction, etc.), this branch characteristically differs, even form agriculture, which on base of its output structure has a considerable similarity with hotels and restaurant business (Fig. 2).

The specific characteristic feature of the food industry can be depicted more obviously by drawing the networks of value-flow between different branches of national economies. Figure 3 shows the value-flow between the different branches of the EU (27) economies. The sizes of the nodes are approximately proportional with the relative importance of the given sector, measured by base of value added. From this figure it is obvious that the food industry has a direct link with agriculture and is a very important supplier of wholesale trade, which is a key sector from the point of view of the development of the real estate, construction, and 
transport sectors. It is important to highlight the strong relations between the food industry as well as education and $\mathrm{R}+\mathrm{D}$ sectors. Put in another way, the food industry plays a rather specific, bridge role in the modern economies: on the one hand it is an important procurator of agricultural and industrial products, on the other hand it is one of the most important suppliers of wholesale trade.

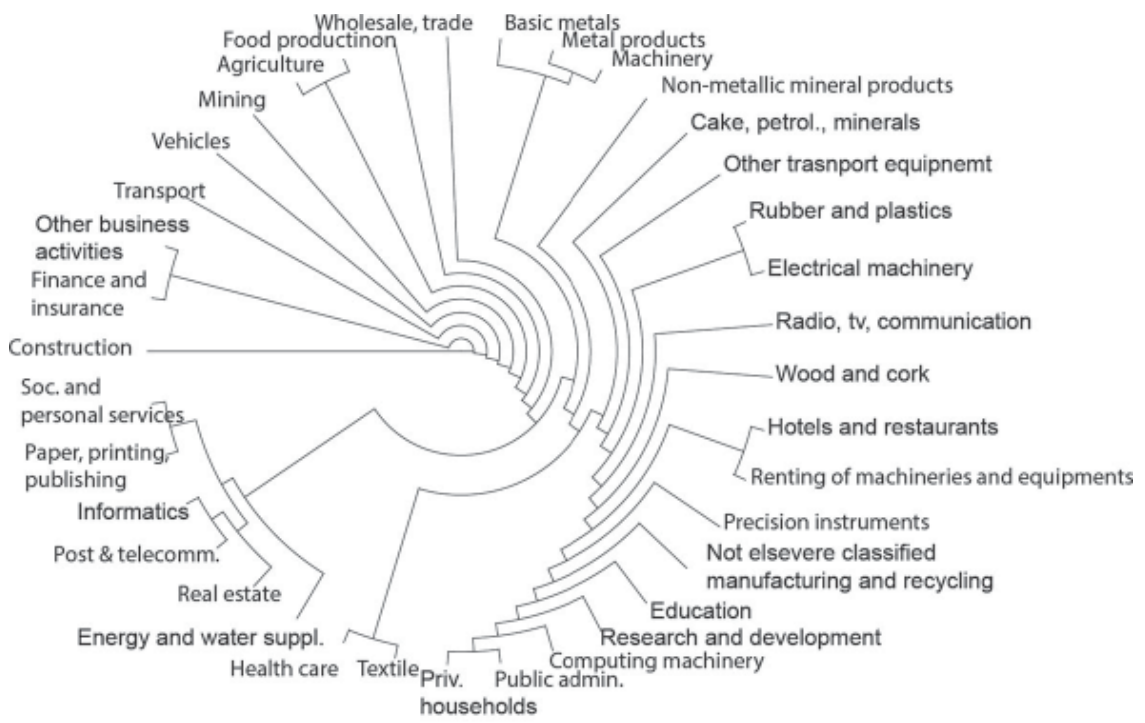

Fig. 1. Cluster analysis of different sectors according to their input structure, based on cumulated input-output table of EU (27) member states

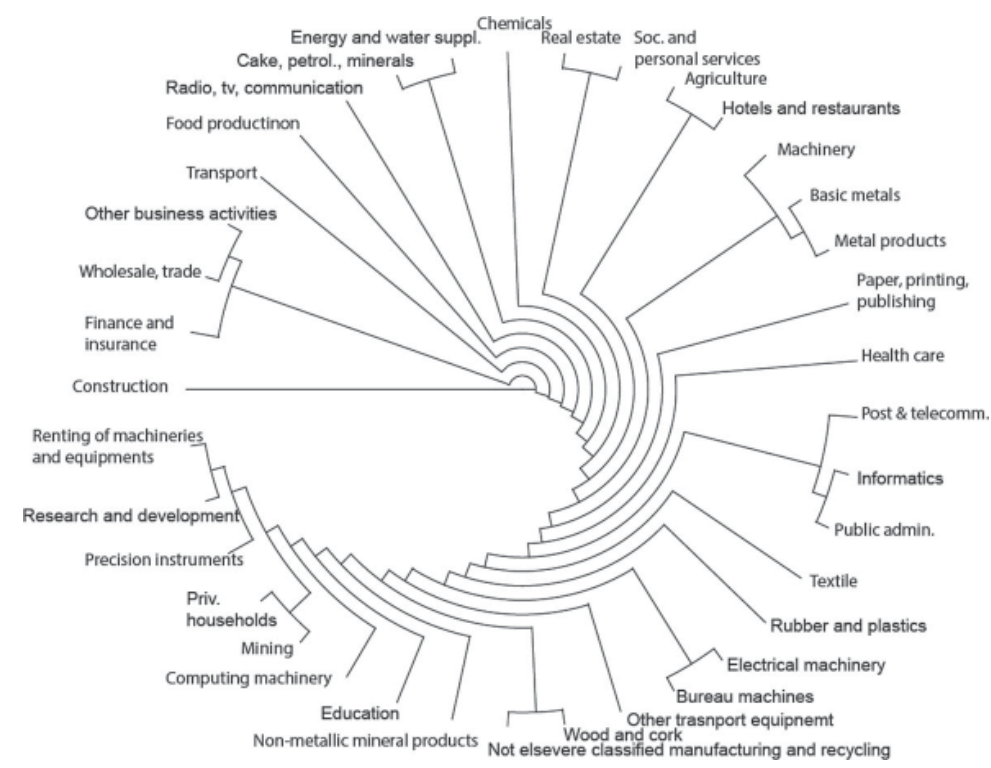

Fig. 2. Cluster analysis of different sectors according to their output structure, based on cumulated input-output table of EU (27) member states 


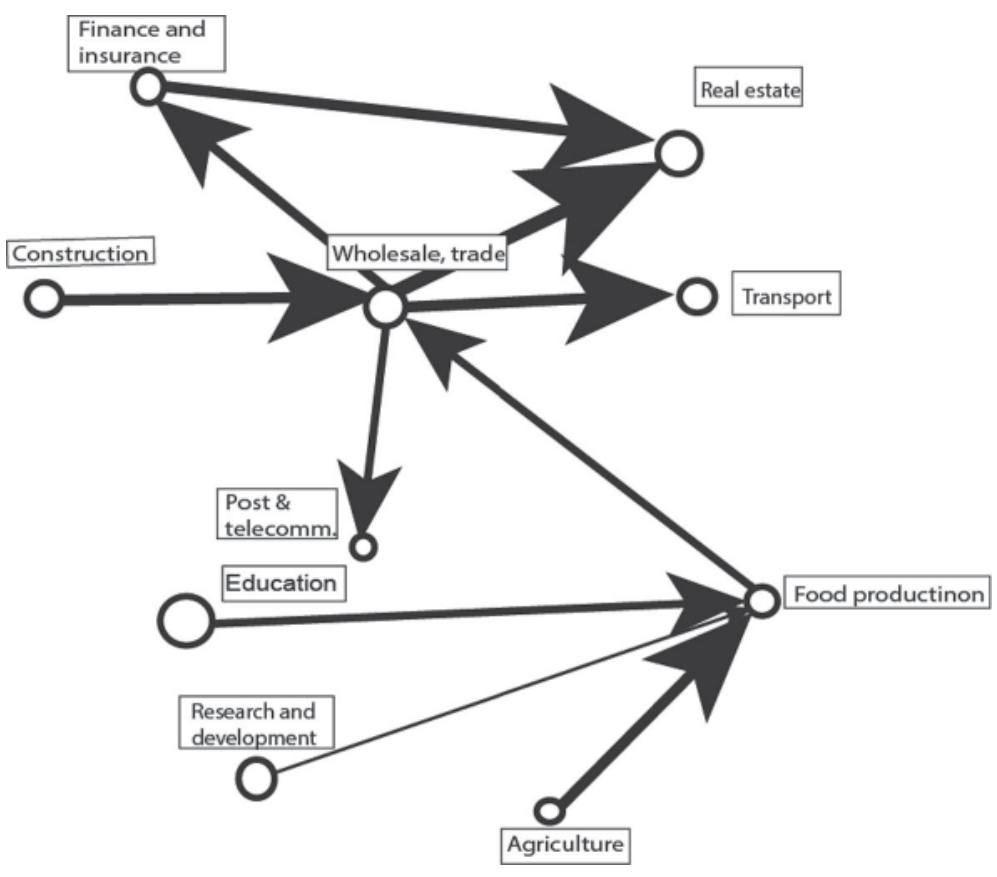

Fig. 3. The most important sectorial relations of food industry on the base is of input-output tables in EU-27

To test the $\mathrm{H}_{2}$ hypothesis, we have determined the stochastic relationships between level of development (expressed in purchasing power parity GDP/capita, based on World Bank electronic database, 2014) and different centrality measures of the food industry. Results for betweenness-centrality and Bonacich power did not yield any conclusive results. In case of four other centrality measurements, a rather weak but a significant inverse relationship could be determined between the level of development and the centrality role of the food industrial sector. In this way the $\mathrm{H}_{2}$ hypothesis cannot be supported.

\section{Conclusions}

As a summary, it can be stated, that the food industry has an above-average centrality on the base is of at least one indicator in most of the economies analysed. In this way the $\mathrm{H}_{1}$ hypothesis can be considered as a proven one. This is an important feature of the sector. At the same time it was not possible to prove a strong, significant relationship between the level of economic development and the centrality of food industry in national economies. This fact does not support the generally accepted theory of the decreasing role of food industry in modern societies.

Research has been supported by OTKA 81594 project. 


\section{References}

Abbasi, A., Hossain, L. \& Leydesdorff, L. (2012): Betweenness centrality as a driver of preferential attachment in the evolution of research collaboration networks. J. Informetr., 6, 403-412.

Albert, R. \& Barabási, A.-L. (2002): Statistical mechanics of complex networks. Rev. Mod. Phys., 74, 47-97.

Bonacich, P. (1987): Power \& centrality: A family of measures. Am. J. Sociol., 92, 1170-1182.

Borgatti, S.P. \& Li, X.U.N. (2009): On social network analysis in a supply chain context. J. Supply Chain Manag., 45, 5-22.

Cohen, A.M., Robinson, E.L. \& Edwards, J.L. (1969): Experiments in organizational embeddedness. Admin. Sci. Quart., 14, 208-221.

Faust, K. \& Wasserman, S. (1992): Centrality and prestige: A review and synthesis. J. Quant. Anthropol., 4, $23-78$.

FooD-MAC (2012) : A European answer to food companies through transnational expertise and surveillance based on examples of key topics to SMEs. European Agro-Food Thematic Network, Brussels, p. 16. Available at www.agro-net.eu/attachments/072_Global_Synthesis_Final_EN.pdf. (Last accessed 10 July 2014)

Fisher, E., \& Vega-Redondo, F. (2006): The linchpins of a modern economy. In AEA Annual Meeting, Chicago, IL. Available at http://www.aeaweb.org/annual_mtg_papers/2007/0107_0800_1502.pdf?origin=publication detail. (Last accessed: 10 July 2014)

FreEman, L.C. (1979): Centrality in social networks conceptual clarification. Soc. Networks, 1, 215-239.

IFM (2010): Value of food \& drink manufacturing to the UK. IFM-Centre_for_Industry_and_Government Cambridge: University of Cambridge, p. 26.

Kim, Y., Chor, T.Y., Yan, T. \& Dooley, K. (2012): Structural investigation of supply networks: A social network analysis approach. J. Oper. Manag., 29, 194-211.

KLeinBerg, J.M. (1999): Authoritative sources in a hyperlinked environment. JACM, 46, 604-632.

KLEINBERG, J M. (2000): Navigation in a small world. Nature, 406, 845-845.

Kuznets, S. (1971): Economic growth of nations - Total output and production structure. The Belknap Press of Harvard University Press, Cambridge, Massachusetts, p. 363.

LAve, L.B. (1995): Using input-output analysis to estimate economy-wide discharges. Envir. Sci. Tech., 29, 420-426.

LeONTIEF, W. (1941): The structure of the American economy, 1919-1939. Oxford University Press, New York, 350 pages.

OECD (2014): STATEXTRACTS: http://stats.oecd.org/Index.aspx?DataSetCode=STAN IO TOT DOM IMP (Last accessed: 01.04.2014)

Opsahl, T., Agneessens, F. \& Skvoretz, J. (2010): Node centrality in weighted networks: Generalizing degree and shortest paths. Soc. Networks, 32, 245-251.

RapetTI, M. (2013): Macroeconomic policy coordination in a competitive real exchange rate strategy for development. J. Globalization Development, 3. (2), 1-31.

Stockman, A.C. (1988): Sectoral and national aggregate disturbances to industrial output in seven European countries. J. Monetary Econ., 21, 384-409.

Tunzelmann, N. \& Acha, V. (2005): Innovation in “low-tech" industries. -in: Fagerberg, J., Mowery, D.C. \& Nelson, R.R. (Eds) The Oxford handbook of innovation. Oxford University Press, Oxford, New York. pp. 407-433.

Vis, B., Van Kersbergen, K. \& Hylands, T. (2011): To what extent did the financial crisis intensify the pressure to reform the welfare state? Soc. Policy Admin., 45, 338-353.

WORLD BANK (2014): http://data.worldbank.org/data-catalog/world-development-indicators. (Last accessed: 01.04.2014) 